\title{
The Contribution of Village Palm Grove to the Cameroonian Rural Economic Development
}

\author{
Pene Zongabiro Nina Pelagie ${ }^{1}$ \\ ${ }^{1}$ College of Economics, Hebei University, Baoding, China \\ Correspondence: Pene Zongabiro Nina Pelagie, PhD student, College of Economics, Hebei University, Baoding, \\ China. E-mail: penenina@yahoo.fr
}

Received: August 7, 2014

Accepted: August 23, 2014

Online Published: August 30, 2014

doi:10.5430/rwe.v5n2p159

URL: http://dx.doi.org/10.5430/rwe.v5n2p159

I would like to acknowledge that the first draft of this paper was published in the Asian Journal of entrepreneurship and sustainability Volume X Issue 2, July 2014. pp 175-200. I thank two anonymous reviewers for their comments and suggestions that helped to improve this current version.

\begin{abstract}
In Cameroon, the 1980s were marked by the economic crisis (falling export revenues) with the direct consequences of unemployment. Thus many were retrenched from the public service, private companies and graduated students engaged in small- income generating activities which later became small businesses. It is in this context that the village palm grove started to bloom as an economic branch and contributes remarkably to the development of business activities in rural areas in Cameroon. Despite, the poorly organized activities small-scale producers deserve a framework that will allow a diffusion of entrepreneurial spirit that will promote the development of rural areas and economic development as well. This article shows how villagers in Cameroon deal with entrepreneurship activities in agricultural business, especially in the business of palm oil. The article aims at introducing the palm grove activity branch as an elevator of entrepreneurship in rural areas; it stresses the characteristics of entrepreneurial actors in this branch of activity, the motivations of small-scale producers towards the production of palm oil and the challenges of the palm grove activity branch. This study show how the business of palm oil is source of main income and contributes to the social welfare of small-scale producers.
\end{abstract}

Keywords: village palm grove, small-scale producers, economic development, entrepreneurship, rural areas

\section{Introduction}

After independence, in 1960, Cameroon adopted a new economic system, as it was the case with other African States after independence to change the system inherited by colonizers. Therefore, in the national productive system, the State had to intervene in a simultaneous manner in the private sector. In so doing, the State had to control the so called strategic sectors namely the development of basic infrastructures, the energy sector, and more. Then the public powers oriented and controlled private action sector through what was called quinquenal plans (Note 1).

As a result, in the mid-1980s, the country experienced a huge economic crisis: the fall of exportation income which led the country to pull itself from the productive system and allowed the advancement of private sectors (African Development Bank, 2007). The aftermath of this crisis led to the increase of a large rate of unemployment. The government employees who lost their employment in the public sector as well as graduates searching for jobs to sustain themselves created some income generating activities. Consequently, those lucrative small activities were later transformed into small enterprises. Under this wave, deflated of the public services and the students, found themselves in economic activity sectors, namely the primary and secondary sector, and a concentration of activities in the tertiary sector.

The economic circumstance (the rise of approximately $40 \%$ in the real effective exchange rate of CFA Francs in 1994, the increase of external debt and the budgetary deficit), leading to these activities, were executed mostly in disorganized manners. It is in this context that the village palm grove became a branch of economic activities. Some deflated of public service went back to their villages to exploit the old plantations of their parents, or to create new ones, enabling the village palm grove to increase to about 100,000 hectares on a surface of 161,000 hectares of palm tree that exist in the country and feeding agro-industries at a level of 12 per cent in palm bunches (Note 2). 
Palm oil provides food for the majority of Cameroonians. Palm oil is also used as raw materials by many manufacturing industries. Finally, a lot of developmental activities around palm grove such as buying and selling of palm oil, including their derivative products are promoted by both sellers and buyers in the local markets. Considering developed activities around the culture of palm oil, one can realize that the small-scale producers have big proportions of plantations $(100,000$ hectares of village palm grove against 61,000 hectares of industrial palm grove). Some current practices of the producers meet the entrepreneurial phenomenon. But despite deployed effort by palm oil producers to serve the country, and despite their day- to- day increasing number, the local production of palm oil does not cover the household needs over the national territory; this opened the way to importation. Although importation was needed, the gap still prevails between the increasing demand and the inadequate supply of palm oil. In Cameroon, the current deficit of 11,000 tons could reach 210,000 tons by year 2015 (Cameroon Village Palm Grove Development Program, 2012). Thus, the village palm grove influence the formation of GDP of rural sector and also impacts on the Cameroon economic development.

\section{Literature Review}

\subsection{Entrepreneur and Economic Development}

Entrepreneurial phenomenon is a complex subject which attracts many researchers from various research domains such as: Management, Psychology, and Economics. For psychologists (Clelland, 1961), entrepreneurship is defined from the psychological characteristics of the entrepreneur. Boutiller and Fournier (2006) revealed two essential dimensions that help us to define an entrepreneurial behavior: it is about the needs that push an individual to accomplish, to search for satisfying solutions on his/her problems and the need of power that is the willingness which is somehow explained to occupy an important place in the system. According to managers, entrepreneurship is connected to the notion of organization (Bygrave \& Hofer, 1991), as it is described by Verstraete and Fayolle (2005), an entrepreneur is one who perceives an opportunity and creates an organization to exploit the opportunity. Economists on the other hand are interested in the impact of entrepreneurs in the creation of wealth and its role in economic development (Stevenson \& Jarillo, 1990). As it is highlighted by Dejardin (2000) through a creation of products and services; entrepreneurs affect and renew economic activities. The discovering of activities and the creation of wealth are therefore attributed to the entrepreneur. For Schumpeter (1939) an entrepreneur stimulates economic growth and economic development through innovation, while Ronstadt (1984) and Shane and Venkataraman (2000), asserts that entrepreneurs used opportunities to create goods and services. The development of entrepreneurial activities that contributes to economic growth of most developed countries such as USA, Japan and New Zealand, is also a lever of economic growth in many emerging or developing countries such as South-Korea, India and China. The important part of China's economic growth over these last three decades is attributed to the development of entrepreneurship or private sector (Li, Meng, and Zhang, 2006, and Chow, 2004).

In Africa context, researchers also supported that entrepreneurial activities would lead to African's economic growth (Black \& Castaldo, 2009), despite the fact that these entrepreneurial activities are mainly developed in small enterprises such as individual small-scale businesses (Daniels 1999, and Kayanula \& Quartey, 2000) and largely dependent from agricultural sectors (Herrington \& Kelley, 2013).

From these definitions and authors views of an entrepreneur in economic development, we are convinced that an entrepreneur is somebody who takes responsibility to change his/her social and economic environment through developmental actions and through creative activities.

\subsection{Characteristics of Entrepreneurial Phenomenon}

As it is complex to study all sides of entrepreneurial phenomenon, this study is limited to some characteristic elements of entrepreneurial phenomenon such as, socio-biographic characteristics of the entrepreneur, the motivating factors to the entrepreneurial act and the constraints connected with the entrepreneurial phenomenon.

Concerning the personal traits of the entrepreneur, the socio- biographic characteristics such as; age, gender and training of the entrepreneur that would differentiate or distinguish the entrepreneur from others. Gibb and Ritchie (1981: 183) propose a theory that suggests that "entrepreneurship can be wholly understood in terms of the types of situation encountered and the social groups to which individuals relate". The Global Entrepreneurship Monitor also revealed that entrepreneurial activities are prevalent among those 25-34 years of age and entrepreneurs are largely men (Herrington \& Kelley, 2013).

About the motivation factors on entrepreneurial act, the Global Entrepreneurship Monitor in sub-Saharan Africa Regional Report (Herrington \& Kelley, 2013) classifies entrepreneurs' motivation into two categories namely: the opportunity driven motives and the necessity driven motives. According to Global Entrepreneurship Monitor, those 
who fall in the last category create enterprise for their own employment because they do not have any choice while those in the first category are real entrepreneurs displaced by real willingness of creating wealth.

According to Shapero and Sokol (1982) there are some factors such as negative displacement (lost job, migrations...) or positive displacement (opportunities, financial support...) could lead some individuals to undertake entrepreneurial activities. Indeed, motivations on entrepreneurship acts are different and they vary. Psychological motivations (independence need, personal accomplishment need, social recognition need); situational motivations (need, opportunism and the financial need), are generally linked with certain catalytic events whose impact is strictly personal and provoke creating action; cultural motivations (entrepreneurs displace these motivations create activities in the cultural milieu that value the group and the individual) and economic motivations (searching for profit) that activate the opportunity creators. Fouda (2002) asserts that, for Cameroonian people, cultural motivation (community mentality) is the main influence for enterprise creation; therefore, its implementation in the Cameroonian context, a particular attention must be put on community mentality.

The constraints of entrepreneurial acts are so many and constitute a barrier to entrepreneurial spirit. Administrative, financial, and cultural constraints are linked with the entrepreneurial phenomenon. Administrative constraints are official procedures that the entrepreneur must achieve alongside the creation and the development of his/her enterprise (World Bank, 2011). In Cameroon, despite the creation of enterprise registration center (one-stop shop), the procedures still remain difficult: for the period of 2009-2010 for ease of doing business the country ranked $168^{\text {th }}$ out of 183 in the world (World Bank, 2011).

The financial aspect is a determinant element for the creation of enterprise. Banks always put tough procedures for lending loans to new entrepreneurs because of lack of information about the capacity of refunding and sometimes the weakness of proposed guarantees. Kauffman (2005) affirms that Small and Medium Enterprises in Africa suffer due to lack of funding which constrain their emergency and future development. Kayanula and Quartey (2000), and Alby, Auriol, and Nguimkeu (2013) also supported that access to capital market remains an obstacle to entrepreneurship development in Africa.

Concerning cultural constraints Hofstede (as cited in Vestraete \& Saporta, 2006) notices that some national culture influence the enterprise creation, such as: masculinity opposes to feminism, or individualism opposes to collectivism (community mentality), and the anxiety of facing risk. Alby et al. (2013) asserted that some social norms in most social network in Africa appeared to have a negative impact on economic outcome. These cultural barriers influences negatively or positively the enterprise spirit, however, the reality of cultural aspects is not accepted everywhere because there are specificities connected to (estimated values) each country or region. So, one is forced to accept that to each culture fits an entrepreneurship form. In Cameroon, this phenomenon can be explained by the community mentality that is a factor of motivation to the entrepreneurial act.

The review of some characteristic elements of entrepreneurial phenomenon stated above show that entrepreneurship is a complex domain whose sides cannot be clarified in this study. Therefore, it is necessary and a must to clarify the objectives of the study.

\section{Objectives of the Study}

The entrepreneurial phenomenon analysis considers a status and the role of promoters in the creation and development of affairs. Various analysis methods have been developed to explain this phenomenon in Africa and the World at large. Our analysis follows the perspective of socio-economic movement and has the following objectives:

-To analyze the practices of entrepreneurial acts of the small-scale producers of palm oil of the Pouma-Cameroon. We are therefore interested in the manifestation of entrepreneurial phenomenon. Kamdem (2001) declares that entrepreneurship is a complex phenomenon that cannot be reduced at simple economic, financial, and material considerations. For this reason, the research must be oriented more towards the understanding of practices and entrepreneurial logic already observed in African settings. So, this study has the objective of appreciating how some practices of palm oil producers meet the entrepreneurial phenomenon (entrepreneurial acts), understand their motivations so as to guide entrepreneurial dynamics that are observed within palm oil small-scale producers of Pouma-Cameroon.

-To respond to the question about the production of palm oil as a support to entrepreneurial development in rural areas, the study aims to use, a case study of small-scale producers of palm oil in the productive basin of Pouma in Cameroon, to present the branch of villages palm grove as an entrepreneurial support or pillar in highlighting the entrepreneurial characteristics of actors of this activity branch; their motivations for the activity and the challenges faced in their daily activities. 


\section{Methodology}

\subsection{Methods and Characteristics of the Population of the Study}

This study uses a case study and inductive model of analysis because it examines the socio-cultural and social-economic context of small-scale producers in order to understand the manifestations of entrepreneurial phenomenon in rural areas. The researcher used both qualitative and quantitative research method. The research instruments were observation, survey, and secondary information (data) analysis. The village palm grove has about 7500 small-scale producers in 7 out of 10 regions of Cameroon. According to their production destination the small-scale producers are classified into two categories: the ones whose sale directly to oil producing industries and the other ones whose final production is transformed into artisanal (local) palm oil. The transformation does not take place in the company having installations such as offices. The industries still has less qualified staff and their salary is not enough. Installations are generally taking place in small hall and depots where they have installed their productive equipment (presses, drum, and barrels serving as ovens, wheel barrows, buckets, and other materials). The production is done into two phases such as production of raw material (palm bunches) and production of final product (palm oil). The first phase is concerned with the establishment of palm grove plantation. For one hectare, 143 plants of palm tree are needed. The plantation produces mature bunches in four years. The second phase counts artisanal palm oil production and the artisanal milling process is done in six steps: the cutting, the detachment, the first cooking, the pressing, the second cooking, and clarification in a filter press or by sedimentation.

This study was interested in small-scale producers who produce artisanal palm oil especially in the Pouma bassin. These producers comprises of the reference (control or target group) population of the study counting about 500 producers sent in four politico-administrative zones (Pouma, Ngok-Mapubi, Matomb and Eséka). From this population, a sample of 100 was drawn. This is about the small-scale producers from 15 villages of two political-administrative zones of the study namely Pouma (litoral Region and Ngok-Mapubi (central Region). The following questions were considered for the selection of the sample: 1) does the participant own a palm grove plantation? 2) Does the participant produce and sell palm oil?

\subsection{Data Collection and Data Analysis}

The data were collected in April and June 2011. The questionnaire, served as an instrument of data collection and it was in French, an official language spoken in this part of Cameroon. The questionnaire was composed of 25 questions divided into three themes, which were meant to get the characteristics elements of small-scale producers: their profile, their motivations for activity and the difficulties encountered.

The following were the 3 questions themes:

Theme 1. The type of small producer: This was composed of 10 questions; it provided information about the typology of the small-scale producers, their socio-demographic and the motivation for the activity.

Theme 2: The activity: This theme constituted of 12 questions and was concerned with characteristics of activity and difficulties encountered in the exercise of the task.

Theme 3: Support to the creation: Composed of 3 questions, this theme revealed information about the environmental influence of creation such as the family, the private institutions and State supports to small-scale producers.

Once the questions were administered, counting proceeded. At this step, out of 104 questions, 4 of them were not treated and were rejected; 100 questions were treated from Statistical Package for Social Science (SPSS17) for descriptive statistics. Then content analysis was used to interpret the results as recommended by Aktouf (1987), and Elo and Kyngas (2008).

\section{Result and Interpretation}

\subsection{Typology of Small-Scale Producers}

Question 4(Q4): Have you been residing in this village?

This question revealed that the small-scale producers are rural and urban origin (see Table 1). 
Table 1. Social origin

\begin{tabular}{llllll}
\hline & & & \multicolumn{2}{l}{$\begin{array}{l}\text { Valid } \\
\text { Percentage }\end{array}$} & $\begin{array}{l}\text { Cumulative } \\
\text { Percentage }\end{array}$ \\
\hline \multirow{2}{*}{ Valid } & Rumber & Percentage & \\
& Urban & 35 & 35.0 & 35.0 & 35.0 \\
& 65 & 65.0 & 65.0 & 100.0 \\
& Total & 100 & 100.0 & 100.0 & \\
\hline
\end{tabular}

Source: Researcher's survey

\subsubsection{Small-Scale Producers from Rural Origin}

These producers constituted 35 per cent of questionnaire respondents. Since their birth, they never left their areas. Agriculture is their main activity and they are involved in different activities such as: coconut, coffee, roots and yam and palm oil. Their major motivation is the need for survival because their basic revenue comes from these activities. In addition, they are motivated by the support of their families because some of the palm oil produce are used as food for the family.

\subsubsection{The Small-Scale Producers from Urban Origin}

The small-scale producers from urban origin constituted 65 per cent of the questionnaire respondents. These, for different reasons (loss employment and retirement) have once resided in town before they could decide to settle in rural zone. In this category we find young people and some retired people.

The young people are those who did not complete their education, and consequently left school without obtaining their certificate. Lacking required qualification, they exercised some vocational work and did not succeed. Their main motivation is to generate money for their survival. Situational motivation is one factor that led these young people to develop entrepreneurial activities and it is related to the concept of negative displacement of Shapero and Sokol (1982).

The retired employees are those who, at the retirement age go to their respective villages and join agriculture activity for additional sources of income; their retirement allowance cannot meet all the needs of the family and especially paying the study fees of the children staying in town. Some non-retired employees are also part of small-scale producers; the agricultural activity is a source of additional revenue to top up their salary. Entrepreneurial activities in this context offer some opportunities for making profits and gaining additional financial resources (Shane and Venkataraman, 2000).

\subsection{Small-Scale Producers' Socio-Demographic Profile}

The socio-demographic characteristics are revealed by variables such as:

Q1: gender, Q2: age, Q5: matrimonial situation

\subsubsection{Gender Distribution}

About the gender, people consider that entrepreneurship is a privilege of men for small-scale producers. This is the reason why the proportion of women was low $(11 \%)$ in the survey. This may be understood by the fact that the activity of palm oil production is painful. Women who try are supported by their husbands and used occasional manpower that they paid while working during the production process; on the other hand, other women helped their husbands. This result is similar to many studies on gender in entrepreneurship, that the proportion of men is bigger as compared to that of women (Herrington \& Kelley, 2013). See Table 2 for gender distribution.

Table 2. Distribution per gender

\begin{tabular}{llllll}
\hline & & Number & Percentage & $\begin{array}{l}\text { Valid } \\
\text { percentage }\end{array}$ & $\begin{array}{c}\text { Cumulative } \\
\text { percentage }\end{array}$ \\
\hline Valid & Male & 89 & 89.0 & 89.0 & 89.0 \\
& Female & 11 & 11.0 & 11.0 & 100.0 \\
& Total & 100 & 100.0 & 100.0 & \\
\hline
\end{tabular}

Source: researcher's survey 


\subsubsection{Age Distribution}

How old are you? This question revealed a weak proportion of 2 per cent of young people whose age is between 18 and 30 years. They found that the activity is painful and prefer activities that can immediately generate revenue, such as operating public transport, using motorcycles. In this study 41 per cent of the survey respondents were between 31 and 50 years. This low proportion in comparison with those above 50 years means that those in that range age are still living in town working in public administration or within the private sector. And In the survey, 57 per cent of the respondents were above 50 years. This strong proportion in this range can be understood by the fact that retired people go back to their villages. On one hand and on the other hand the responsibilities of the head of the family who must source more revenue and income to sustain the family needs. See Table 3 for age distribution.

Table 3. Distribution per age

\begin{tabular}{llllll}
\hline & & Number & Percentage & percentage & $\begin{array}{l}\text { Cumulative } \\
\text { Percentage }\end{array}$ \\
\hline Valid & $18-30$ years & 2 & 2.0 & 2.0 & 2.0 \\
& $31-50$ years & 41 & 41.0 & 41.0 & 43.0 \\
& Above 50 years & 57 & 57.0 & 57.0 & 100.0 \\
& Total & 100 & 100.0 & 100.0 & \\
\hline
\end{tabular}

Source: Researcher's survey

\subsubsection{Matrimonial Status}

To the question: Are you married? Responses indicate that enterprise spirit is more dominant to married people with 89 per cent of the respondents than to the single ones and the widows. This can be explained by the family burden, the satisfaction of familial needs (feeding, clothing, and schooling of children), and the important manpower that the palm oil production need, the help of the spouse and children being important. The Community mentality pushes small-scale producers to develop entrepreneurial activities with an aim of meeting the needs of the large family members (Alby et al., 2013). See Table 4 for matrimonial status distribution.

Table 4. Matrimonial status

\begin{tabular}{lllll}
\hline & Number & Percentage & $\begin{array}{l}\text { Valid } \\
\text { Percentage }\end{array}$ & $\begin{array}{l}\text { Cumulative } \\
\text { Percentage }\end{array}$ \\
\hline Valid Married & 89 & 89.0 & 89.0 & 89.0 \\
Single & 8 & 8.0 & 8.0 & 97.0 \\
Widow & 2 & 2.0 & 2.0 & 99.0 \\
Divorced & 1 & 1.0 & 1.0 & 100.0 \\
Total & 100 & 100.0 & 100.0 & \\
\hline
\end{tabular}

Source: Researcher's survey

The socio-characteristics have revealed that the age of actors of village palm grove is comprised between 18 and above 50 years. Majority of them are male and married. The small-scale producers are therefore adult entrepreneurs.

\subsection{Small-Scale Producers' Motivations and Constraints}

\subsubsection{Small-Scale Producers' Motivations}

To the question: What are the motivation backgrounds of your exploitation? Responses revealed that the motivations of small-scale producers for exploitation of palm grove are varied and depend on each category of them. The principal motivations are connected with some events such as the loss of employment, retirement, the desire of collective welfare (supporting the family) and the search for profit. They could then be grouped into three categories: situational motivations, cultural motivations and economic motivations.

Situational motivations refer to some factors that lead to the decision to start agricultural activities. To some young people, palm oil production came after the loss of small vocational jobs because of not being qualified, for the small-scale producers' beyond 50 years old, the retirement was at the beginning of the establishment of their plantations, and to the small-scale producers from rural areas, it is a source of revenue in order to meet the essential 
needs (feeding, clothing, healthcare, etc.). In this aspect 60 per cent of small-scale producers exploit the palm grove for survival reasons (Boutiller and Fournier, 2006). (See Table 5 for situational motivations distribution).

Table 5. Motivations to activity $=$ survival needs

\begin{tabular}{llllll}
\hline & & Number & Percentage & $\begin{array}{l}\text { Valid } \\
\text { percentage }\end{array}$ & $\begin{array}{l}\text { Cumulative } \\
\text { Percentage }\end{array}$ \\
\hline Valid & No & 40 & 40.0 & 40.0 & 40.0 \\
& Yes & 60 & 60.0 & 60.0 & 100.0 \\
& Total & 100 & 100.0 & 100.0 & \\
\hline
\end{tabular}

Source: Researcher's survey

The cultural motivations (community attachment) show that 53 per cent of the respondents have created plantations to support their families; so, the palm grove is a source of revenue that should be exploited by the family members (Fouda, 2002). (See Table 6 for cultural motivations distribution)

Table 6 . Motivation to activity = supporting the family

\begin{tabular}{|c|c|c|c|c|c|}
\hline & & Number & Percentage & $\begin{array}{l}\text { Valid } \\
\text { percentage }\end{array}$ & $\begin{array}{l}\text { Cumulative } \\
\text { Percentage }\end{array}$ \\
\hline \multirow[t]{3}{*}{ Valid } & No & 47 & 47.0 & 47.0 & 47.0 \\
\hline & Yes & 53 & 53.0 & 53.0 & 100.0 \\
\hline & Total & 100 & 100.0 & 100.0 & \\
\hline
\end{tabular}

Source: Researcher's survey

The economic motivations: the small-scale producers' searching for profit is those who make important business figures and have plantations that generally exceed three hectares. As shown in (Table 7) 81 per cent of the questionnaire respondents are also motivated by profit reasons.

Table 7. Motivations to activity $=$ searching for profit

\begin{tabular}{llllll}
\hline & & & & $\begin{array}{l}\text { Valid } \\
\text { percentage }\end{array}$ & $\begin{array}{l}\text { Cumulative } \\
\text { percentage }\end{array}$ \\
\hline \multirow{2}{*}{ Valid } & No & 19 & 19.0 & 19.0 & 19.0 \\
& Yes & 81 & 81.0 & 81.0 & 100.0 \\
& Total & 100 & 100.0 & 100.0 & \\
\hline
\end{tabular}

Source: Researcher's survey

It should also be noted that the improvement of revenue is a variant of economic motivation because to some small-scale producers, the exploitation of palm oil is a business opportunity that provides additional source of income on top of the prime earnings (retirement pension, paid employment, revenue generating activity).

\subsubsection{Small-Scale Producers' Constraints}

Constraints that face to small scale producers in their activity are of two types; Endogenous constraints and exogenous constraints. Endogenous constraints are linked to the small-scale producers' activities and have three levels: Bunch production (plantation services), the transformation (the low productivity of artisanal milling) and the commerce (the market is less organized). While exogenous constraints are about the lack of infrastructure such as roads (it is difficulty for the products to reach the local markets), training (lack of technical training), financial constraints (lack of financial support) and cultural constraints (agricultural activities seem to be useless to most young people). As noticed by Kauffman (2005), financial constraints mostly impact negatively on the development of activities, to acquire required equipment adapted for modern mailing process capable to improve the quality of palm oil produced small-scales producers need financial resources from formal financial system such as banks and not from family financial support that is insignificant to support sustainable entrepreneurial activities. 


\subsection{Support to Small-Scale Producers' Activities}

To the question: Did your family encourage you for the creation of your plantation?

The family is the first environment that encouraged the initiative of small-scale producers; here, 97 per cent of respondents showed that they were encouraged by their families. The State and some Non-Governmental Organizations (NGOs) have also put in their support (technical training), but remained insufficient to the needs of small-scale producers.

\section{Discussion}

This study has demonstrated that, the village palm grove that is part of the primary sector, contributes in a significant manner to the development of economic activities in rural areas despite the small size of the activities. Small-scale producers through the developmental activities and business of palm oil, shape the landscape of entrepreneurship in rural areas. Small-scale producers provided agro-industries with palm bunch and palm oil produced is used as raw materials for manufacturing industries (Dejardin, 2000). Furthermore, income generated from palm oil is used for the social welfare of small-scale producers and their respective families. The analysis of entrepreneurial phenomenon to the small-scale producers shows the following facts:

1. The profile analysis of small-scale producers reveals that this profile is not far from what is attributed to any entrepreneur (most of them are males) and this result is more similar to previous surveys of Global Entrepreneurship Monitor on impact of gender on entrepreneurial activity; that men are more willing than women to pursue entrepreneurial activity (Herrington \& Kelly, 2013).

2. The identified motivations to the small-scale producers lead to form two categories according to the Global Entrepreneurship Monitor classification opportunity creators and necessity creators. So, on those of small-scale producers searching for profit are classified under opportunity creators, and those stimulated by the need of money and the support of the family classified under the necessity creators. Moreover, motivations depend on economic transformations (on the micro level) and social transformations (retirement, loss of employment).

3. Like any entrepreneur, small-scale producers face a lot of challenges some of them are associated with their activity and others with the environmental creation. The financial and cultural constraints and the lack of training constitute a barrier against their activity development (Kayanula and Quartey, 2000). The survey revealed that majority of small-scale producers did not have necessary technical training for the production of palm oil, and the management of this activity. A training programme for management activities could have a positive impact on productivity of small scale producers of palm oil.

The small-scale producers like other Cameroonian entrepreneurs, face almost the same impediments in their activity. So, our recommendations in the framework of this study, favor the reinforcement of entrepreneurial spirit developed by the small-scale producers through their activities. It is a matter of:

-Stimulating entrepreneurs, public authorities, and any other actors in the Cameroonian private sector to participate in the establishment of entrepreneurs' class, help to boost the growth of Cameroon Economic Development. Particularly, there is a necessity to promote entrepreneurial activities in rural areas where poverty is more severe.

-Improving the exercise of small-scale producers' activities for the difficulties related to villages palm grove and setting new financial tools suitable for rural areas such as Mutual Saving and Loans that would give loans to enable small-scale producers to participate in capital accumulation and modernized production tools which are a requirement to small-scale producers.

-Encouraging young people to engage in production activity and calling upon parents' to educate their children towards technical trainings and teach them how to develop entrepreneurial activities.

-Improving the affair climate with particular actions on fiscal, basic infrastructure could participate in a significant manner on the Cameroon entrepreneurial promotion. It is necessary to adjust the institutional and judicial framework in establishing laws and rules that fit into micro activities and proceeding to the fiscal exemptions for the young entrepreneurs. The establishment of business legislation suitable to the very small enterprises that comprise the very important proportion of enterprises representing about 75 percent of the Cameroonian enterprises in all the economic sectors is necessary (Cameroon General Enterprise Census, 2009).

-Balanced enterprises distribution. The concentration of enterprises in Cameroon's big towns such as Yaoundé, Douala, and Bafoussam, could explain the fact that product expansion operates directly at the custom and the 
distribution costs are reduced at a minimum level. The development of road infrastructures facilitates the development of enterprises. The main societies could in fact, open more branches beyond big towns and relocate some of their activities towards small towns where manpower is relatively cheap and available. The distribution in water and electricity is another problem to entrepreneurs, especially the weak rural zone coverage which remains the barrier for installing enterprises in these zones that have cheap manpower, but also with an extension of internet network, useful for the functioning of activities of any enterprise whatever the localization (urban or rural zone).

\section{Conclusion}

This study is about Village palm grove as development lever to the entrepreneurial activity in rural areas, it advocates in favor of the promotion of entrepreneurship in rural areas where poverty is more severe. Although, the developed activities in that zone are less structured, they have characteristics of entrepreneurial phenomenon and contribute to social welfare of small- scale producers as well to economic development in rural zone. Therefore; we recommend that; further researches in entrepreneurial domain should be done to bring different development actors (State, NGOs, Funders, Civil society, and investors) to make their contributions in promoting entrepreneurial activities in rural areas. On the other hand, in the Cameroonian context, researchers should also emphasize on manifestation specificity of this phenomenon that is influenced by proper characteristics to its institutional and economic environment.

\section{Acknowledgements}

The author thanks Mr. Ngom Emmanuel for introducing her to small-scales producers who filled out the questionnaires.

\section{References}

African Development Bank. (2007). Cameroon/ Structural Adjustment Program III (PASIII). Retrieved $4^{\text {th }}$ February 2014 , from http://www.afdb.org/fileadmin/uploads/afbd/Document/EvaluationReports/19614240-FR-CAMEROON-PAS-II I.PDF

Aktouf, O. (1987). Méthodologie des sciences sociales et approches qualitatives des organisations (Social sciences Methodology and qualitative approach to organizations). Montreal: Les presses de l'Université du Québec.

Alby, P., Auriol, E., \& Nguimkeu, P. (2013). Social barriers to entrepreneurship in Africa: the forced mutual help Hypothesis. Retrieved 10 June 2014, from http://www.cmi.no/file/?2371

Black, R., \& Castaldo, A. (2009). Return migration and entrepreneurship in Ghana and Cote d'Ivoire: The role of capital transfers. Tjjdschriff voor economishe en sociale geografie, 100(1), 44-58.

Boutillier, S., \& Fournier, C. (2006). Artisanat: la modernité réinventée (Craft: modern reinvention). Paris, Harmattan.

Bygrave, W.D., \& Hofer, C.W. (1991). Theorizing about Entrepreneurship. Entrepreneurship Theory and Practice, $16(2)$.

Chow, G.C. (2004). Economic reform and growth in China. Annals of Economics and Finance, Society for AEF, 5(1), 127-152.

Daniels, L. (1999). The role of small enterprises in the household and national economy in Kenya: a significant Contribution or a last resort. World Development, 27(1), 55-65.

Dejardin, M. (2000). Entrepreneuriat et croissance economique: une conjunction favorable? (Entrepreneurship and economic growth: a favorable conjunction?). Reflets et perspectives de la vie économique Tome, XXXIX(4). Retrieved 14 April 2014, from http://128.118.178.162/eps/dev/papers/0306/0306003.pdf

Drucker, P. (1985). Les Entrepreneurs (the entrepreneurs). Editions Tendances Actuelles: L'Expansion Hachette. Jean Claude Lattes.

Elo, Satu, \& Helvi, Kyngas. (2008). The qualitative content analysis process. Journal of advanced nursing, 62(1), 107-115.

Fouda, O. M. (2002). La perception de l'esprit d'entreprise chez les jeunes des différents groupes ethniques camerounais (The perception of entrepreneurship among young people from different ethnic group in Cameroon), 
paper presented at the conference: "Actes Deuxième congrès de l'entrepreneuriat, champ de l'entrepreneuriat et dynamique des sociétés", Bordeaux.

Gibb, A., \& J. Ritchie. (1981). Influences on Entrepreneurship: A Study over Time. In Bolton Ten Years On, Proceedings of the UK Small Business Research Conference, Nov. 20-21. Polytechnic Central, London.

Herrington. M., \& Kelley, D. (2013). Global Entrepreneurship monitor. Sub-Saharan Africa regional Report. $\begin{array}{lllll}\text { Retrieved } & 17 & \text { April } & 2014, & \text { from }\end{array}$ http://www.gemconsortium.org/docs/2009/gem-2012-sub-saharan-africa-regional-report

Kamdem. E. (2001). Entrepreneuriat et sciences sociales en Afrique (Entrepreneurship and social sciences in Africa. International Management, 6(1), 17-31.

Kauffman, C. (2005). SMEs financing in Africa. OCDE development centre: Policy Insights $N^{\circ} 7$. Retrieved $2^{\text {nd }}$ February 2014, from http://www.oecd.org/dev/34908457.pdf

Kayanula, D., \& P. Quartey. (2000). The policy environment for promoting small medium-sized enterprises in Ghana and Malawi, IDPM Finance and Development Research Programme Working Paper Series 15.

Li, H., Meng, L., \& Zhang, J. (2006). Why do entrepreneurs enter politics: Evidence from China, Economic Inquiry, 44(3), 559-578. http://dx.doi.org/10.1093/ei/cbj031

Mc Clelland, D.C. (1961). The achieving society. London: The Free Press.

Republic of Cameroon: National Institute of Statistics/ General Enterprise Census. (2009). Retrieved $4^{\text {th }}$ February 2014, from http://www. Statistics- cameroon.org

République du Cameroun: Ministère de l'Agriculture et du Développement Rural/Programme de Développement des Palmeraies Villageoises. (2012). document de la Phase II, (Ministry of Agriculture and Rural Development Palm Grove Development Program, document of Phase II). Yaoundé.

Ronstadt, R.C. (1984). Entrepreneurship. Dover. MA: Lord Publishing.

Shapero, A., \& Sokol, L. (1982). The social dimension of entrepreneurship. In Kent, C.A., Sexton, D.L., \& Vesper, K.H. (Eds.), Encyclopedia of entrepreneurship (pp. 72-90). Englewood Cliffs NJ, Prentice. Hall.

Shumpeter, J.A. (1939). Business Cycle, Vol. 1. New York: Mc Graw-Hill.

Stevenson, H.H., \& Jarillo, J.C. (1990). A paradigm of entrepreneurship: Entrepreneurial Management. Strategic Management Journal, 11, 17-27.

Verstraete, Thierry, \& Fayolle, Alain. (2005). Paradigmes et entrepreneuriat (Paradigms and entrepreneurship). Revue de Entrepreneuriat, 4(1), 33-52.

Verstraete, Thierry, \& Saporta, Bertrand. (2006). Création d'Entreprise et Entrepreneuriat (Business creation and $\begin{array}{lllll}\text { Entrepreneurship). } & \text { Retrieved } & 3^{\text {rd }} & \text { February } & 2014,\end{array}$ http://thierry-verstraete/pdf/adreg\%2010/\%20Verstraete\%20saporta\%20complet.pdf

World Bank/Doing Business. (2011). Making a difference for entrepreneurs. Retrieved 21st September 2013, from http://www.doingbusiness.Org./ /media/GIAMB/Doing\%20Business/Document-AnnualReports/English/DB11fullReport.pdf

\section{Notes}

Note 1. A Quinquenal plan means five years plans.

Note 2. This extract was withdrawn from Village Palm Grove Development Program document from Cameroonian Minister of Agriculture and Rural development in french (Ministère de l'Agriculture et du Développement Rural/Programme de Développement des Palmeraies Villageoises (2012) document de la Phase II), P11. 